\title{
Effect of oil type and batter ingredients on the properties of deep-frying flakes
}

\author{
Vipa SUROJANAMETAKUL ${ }^{1}$, Sujinna KARNASUTA², Prajongwate SATMALEE ${ }^{1 \star ~(D) ~}$
}

\begin{abstract}
Deep-fried batter food products have recently gained popularity since they are both appetizing and palatable. However, deep-fried food contains high oil content, promoting increasing health concerns of consumers. Oil absorption reduction batter formulae and new types of cooking oil are showing improved customer demand. Coconut oil is gaining interest as a healthy food selection but information comparing coconut oil to palm oil for frying is limited. Effects of oil type and ingredients on the properties of deep-fried batter were investigated. Density of the fried flakes differed slightly between the samples. Flakes fried in coconut oil had lower density, higher oil absorption, and better texture than those fried in palm oil. Addition of whey protein and soluble fiber to the samples increased oil absorption with texture better than the control. Oil absorbed by fried flakes with added whey was greater than those with added fiber, and oil content increased as the amount of whey increased. Results showed that coconut oil was not a good frying medium since high oil content was absorbed into the food pieces. Addition of whey and fiber did not reduce oil uptake but modified the texture of the fried flakes.
\end{abstract}

Keywords: deep-fried food; oil type; whey protein; soluble fiber; fried flake characteristics.

Practical Application: oil uptake and texture of the fried flake was modified by the batter formulation.

\section{Introduction}

Fried batter food products are widely consumed throughout the world since they are both appetizing and palatable. However, recently, there have been growing concerns about the health problems associated with consumption of fried batter food due to the large oil content. Many chemical and physical processes occur during food frying including starch retrogradation, the Maillard reaction, porosity changes and oil degradation (Mellema, 2003). Oil uptake by fried products is a spontaneous phenomenon. Budžaki \& Šeruga (2005) pointed out that during the frying process, pores are formed from the evaporation of water at the food surface. This results in oil content increasing, while capillary pressure retains the oil through microstructure porosity and fracture during cooling (Moreira et al., 1997; Ziaiifar et al., 2010). Intensive research has focused on reducing oil absorption into food pieces during the frying process. Olson \& Zoss (1985) suggested that a hydrocolloid coating could reduce oil absorption, while Debnath et al. (2003) claimed that pre-frying could reduce oil uptake by $50 \%$. These methods are not suitable for use in households because of difficulty in preparation.

Batter formulation is the most preferable method for reducing oil absorption. Brannan et al. (2014) stated that proteins and non-protein hydrocolloids could be used as oil absorption reduction ingredients. These substances act as an invisible film coating which retards oil uptake into the batter (Varela \& Fiszman, 2011). The effect of flour on oil absorption remains poorly understood. Mohamed et al. (1998) reported that pregelatinized rice flour increased oil absorption, while Shih \& Daigle (1999) and Nakamura \& Ohtsubo (2010) found that rice flour reduced oil uptake. Addition of hydrocolloids reduced oil uptake due to their thermogelation properties
(Primo-Martín et al., 2010), while addition of soy flour resulted in oil content reduction (Nasiri et al., 2012).

The type of oil used also influences oil uptake by fried products. Kita et al. (2007) reported that oil uptake depended on the type of oil used for frying. Coconut oil has recently attracted interest from consumers due to its unsaturated fatty acid content. Previous reports indicated that coconut oil could be considered as a good frying media (Lu \& Tan, 2009). However, coconut oil is more expensive than palm oil which is usually used as the frying medium due to its high smoke point, oxidation resistance (Mba et al., 2015) and consumer acceptance (Khan et al., 2000). French fries fried using palm oil had lower oil content than those fried in olive, sunflower and rapeseed oil (Kita \& Lisínska, 2005).

Thus, here, the effects of oil type (coconut oil and palm oil) and batter formulation (whey protein and soluble fiber) on bulk density, texture and oil absorption of fried flakes were investigated to better understand the oil absorption phenomenon on fried products.

\section{Materials and methods}

Wheat flour, rice flour and cooking oil (coconut and palm oil) were purchased from a local market, while whey protein and soluble fiber (fibruline ${ }^{\circledR}$ ) were sourced from a food supplier.

\subsection{Frying oil viscosity}

Viscosity of the frying oil was determined using a Brookfield Viscometer (DV-III, Brookfield, USA) at room temperature $\left(25^{\circ} \mathrm{C}\right)$ and recorded as centipoise $(\mathrm{cP})$. 


\subsection{Batter preparation}

Batter was prepared as shown in Table 1. Each formula was mixed and stored in a closed container until required for use to prevent moisture absorption.

\subsection{Batter frying}

For each batter recipe, $70 \mathrm{ml}$ of water was added to $100 \mathrm{~g}$ of dry mix. Two liters of cooking oil were heated in a commercial bench-top deep-fryer (Tefal, France) until reaching $180^{\circ} \mathrm{C}$. Then, the batter was fried for 2 minutes following the method of Shih \& Daigle (1999). The fried flakes were cooled on a paper towel for 10 minutes and stored in an airtight container until required for further analysis.

\subsection{Fried batter flake characteristics}

Bulk density of fried flakes was measured as described. The fried flakes were poured into a $200 \mathrm{ml}$ glass beaker until it was full. The weight of $200 \mathrm{ml}$ volume of flakes was measured and bulk density was determined. Flakes with higher density underwent lower expansion during the cooking process.

A Texture Analyzer (Ta.XT.plus, Stable Micro, UK), equipped with a mini Ottawa Cell was used to measure hardness of the fried flakes as the maximum force and stiffness as the gradient of maximum force.
Oil in $2.5 \mathrm{~g}$ of the fried flakes was extracted by hexane for 6 hours at ambient temperature according to the method of Dogan et al. (2005a).

The sensory evaluation was carried out according to Nakamura \& Ohtsubo (2010). The fried flakes were subjectively scored by 12 panelists for their appearance, aroma, crispiness, hardness, taste and overall desirability. Maximum score was 5 and minimum score was 1 (Table 2). Scores for the control sample were 3 for all parameters. The test aimed to determine the difference between the experimental samples and the control.

\subsection{Statistical analysis}

All experiments were carried out in triplicate. Results were reported as average values with standard deviations. Analysis of variance (ANOVA) and Duncan's multiple range test (DMRT) at $p=0.05$ were used to determine differences between treatments using SPSS version 12.0.

\section{Results and discussion}

\subsection{Bulk density of the fried flakes}

Bulk density was related to the expansion of the batter. A higher expansion gave a larger volume which resulted in lower weight. Samples fried in palm oil had similar bulk density. Lowest flake density was recorded for samples fried in coconut

Table 1. Batter composition.

\begin{tabular}{|c|c|c|c|c|c|c|c|}
\hline Formula (\%) & Wheat flour & Rice flour & Sugar & Salt & Baking powder & Whey protein & Soluble fiber \\
\hline Control & 55.00 & 10.00 & 30.00 & 1.00 & 4.00 & - & - \\
\hline Whey $5 \%$ & 52.25 & 9.50 & 28.50 & 0.95 & 3.80 & 5.00 & - \\
\hline Whey 10\% & 49.50 & 9.00 & 27.00 & 0.90 & 3.60 & 10.00 & - \\
\hline Fiber 5\% & 52.25 & 9.50 & 28.50 & 0.95 & 3.80 & - & 5.00 \\
\hline Fiber $10 \%$ & 49.50 & 9.00 & 27.00 & 0.90 & 3.60 & - & 10.00 \\
\hline
\end{tabular}

Table 2. The sensory evaluation form. The control sample was rated 3 for all parameters.

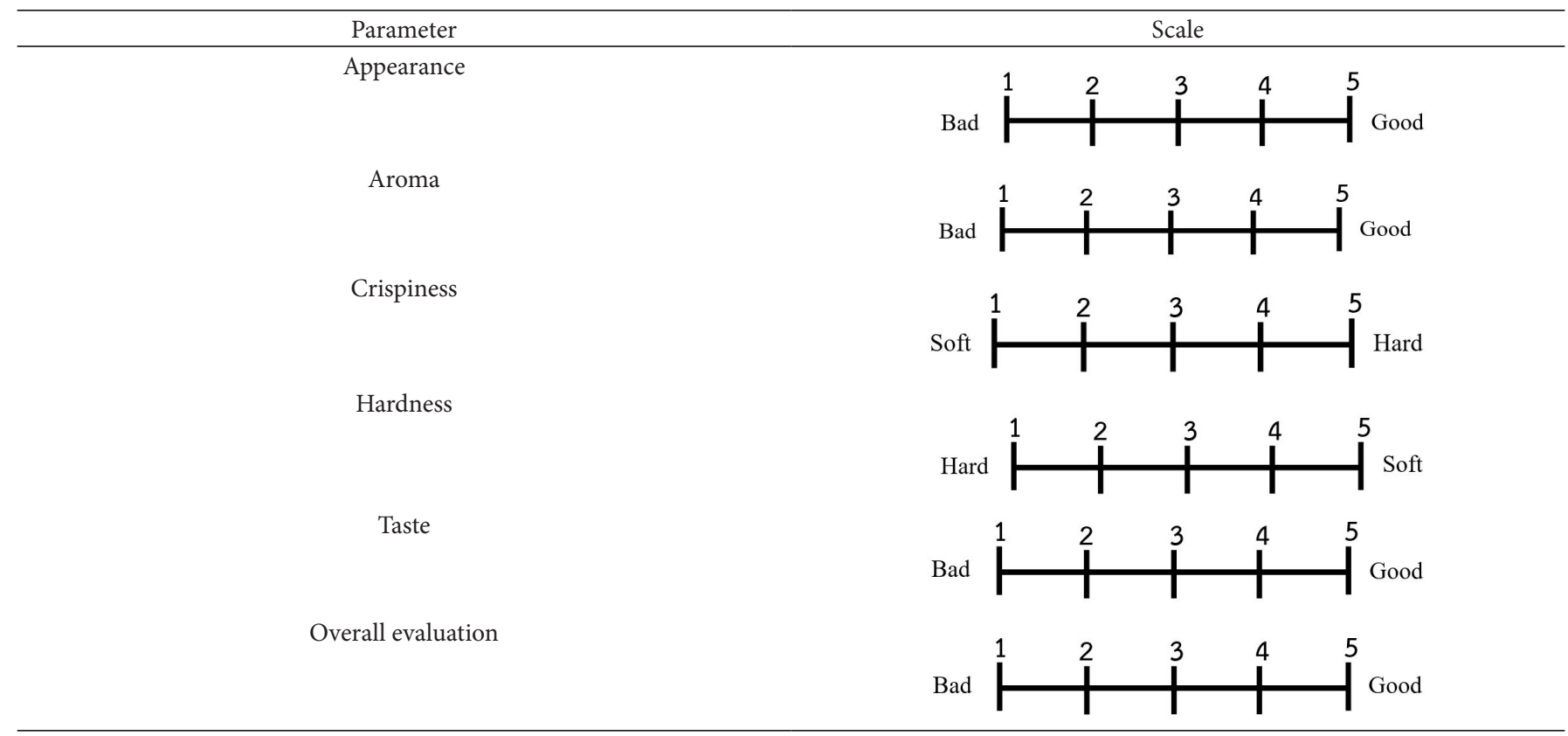


oil with $10 \%$ whey added (Figure 1). Control flakes fried in palm oil had slightly lower bulk density than those fried in coconut oil because of the lower expansion of the flakes. This could result from different viscosities of the cooking oils. The viscosity of coconut oil was $73.30 \pm 0.14 \mathrm{cP}$, while the viscosity of palm oil was $89.35 \pm 0.21 \mathrm{cP}$. Coconut oil had lower viscosity than palm oil which negatively correlated to the heat transfer coefficient (Debnath et al., 2012) and affected expansion of the batter during frying. Krokida et al. (2000) reported that higher oil viscosity resulted in lower porosity values of fried products. Addition of fiber had minimal effect on bulk density for both cooking oils while adding whey reduced bulk density of coconut oils.

Oil bulk density possibly related to the porosity of the fried batter. Dogan et al. (2005b) stated that porosity referred to the pore volume relative to the matrix volume. Moreover, porosity also affected the crispiness perception of the fried batter (van Koerten et al., 2015).

\subsection{Texture of the fried flakes}

Hardness and stiffness of the fried flakes are shown in Table 3. Hardness was measured as the maximum force (Voong et al., 2018), while stiffness was calculated from the initial slope of the first peak (van Koerten et al., 2015). Hardness and stiffness values of flakes fried with coconut oil were lower than palm oil for both parameters.

Hardness of flakes with added whey protein and fiber was lower than control and decreased with increasing amounts. Stiffness showed the same trend as the hardness. Hardness values showed a negative relationship to the porosity of the fried products, while stiffness related to crust brittleness (van Koerten et al., 2015). Addition of protein and fiber resulted in textural changes due to the disruption of the starch matrix (Dueik et al., 2014).

\subsection{Oil absorption of the fried flakes}

Absorption of oil by fried products occurs during cooling. Oil on the surface is absorbed due to capillary pressure and product microstructures such as porosity (Moreira et al., 1997; Ziaiifar et al., 2010; Voong et al. 2018). Some studies noted that oil origin and viscosity did not affect oil uptake (Kim et al., 2010) which did not concur with our results. Flakes fried in coconut oil had higher oil absorption than palm oil for all samples (Figure 2). Gertz (2014) stated that oil viscosity impacted on the migration of oil to the products.
Oil absorption in the control was lower than whey and fiber added samples for both cooking oils. Zhang et al. (2018) reported that porosity related to oil absorption. This could explain why whey protein resulted in higher oil content than fiber added samples. Higher porosity disrupts the starch matrix resulting in higher oil absorption (Mohamed et al., 1998; Dueik et al., 2014). Similar results were reported by Dogan et al. (2005a) and Pęksa et al. (2010), while Zeng et al. (2016) recorded a reduction in oil content in products. The type of fiber used in the formula affected the amount of oil absorption.

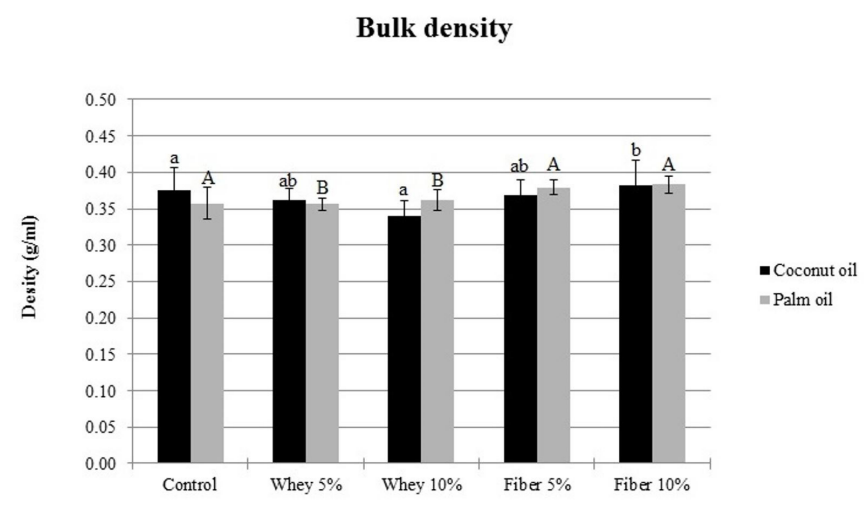

Figure 1. Bulk density of the fried flakes using coconut and palm oil. Lowercase letters compared means between treatments fried with coconut oil. Capital letters compare means between treatments fried with palm oil.

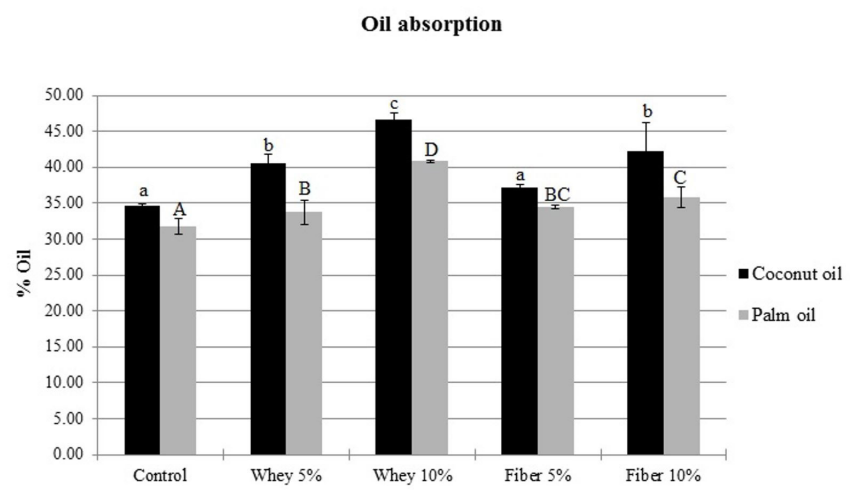

Figure 2. Oil absorption of the fried flakes using coconut and palm oil. Lowercase letters compared means between treatments fried with coconut oil. Capital letters compare means between treatments fried with palm oil.

Table 3. Hardness and stiffness of the fried flakes using different cooking oils

\begin{tabular}{ccccccc}
\hline \multirow{2}{*}{ Formula } & \multicolumn{2}{c}{ Coconut oil } & & \multicolumn{2}{c}{ Palm oil } \\
\cline { 2 - 3 } \cline { 6 - 7 } & Hardness $(\mathrm{g})$ & Stiffness $(\mathrm{g} / \mathrm{sec})$ & & Hardness $(\mathrm{g})$ & \multicolumn{1}{c}{ Stiffness $(\mathrm{g} / \mathrm{sec})$} \\
\hline Control & $7,734.81 \pm 1,144.55 \mathrm{a}$ & $1,925.77 \pm 293.06 \mathrm{a}$ & & $9,609.23 \pm 1,337.94 \mathrm{a}$ & $2,450.63 \pm 316.04 \mathrm{a}$ \\
Whey $5 \%$ & $5,286.81 \pm 1,159.58 \mathrm{~b}$ & $1,332.25 \pm 296.09 \mathrm{a}$ & & & $7,093.91 \pm 2,267.08 \mathrm{~b}$ & $1,672.04 \pm 542.52 \mathrm{c}$ \\
Whey $10 \%$ & $2,926.50 \pm 719.54 \mathrm{c}$ & $747.78 \pm 183.43 \mathrm{c}$ & & $3,994.82 \pm 783.36 \mathrm{~d}$ & $1,022.23 \pm 178.26 \mathrm{~d}$ \\
Fiber $5 \%$ & $5,241.78 \pm 1,664.20 \mathrm{~b}$ & $1,445.37 \pm 488.93 \mathrm{a}$ & & $7,575.88 \pm 1,535.51 \mathrm{~b}$ & $2,008.63 \pm 422.94 \mathrm{~b}$ \\
Fiber 10\% & $2,811.06 \pm 517.63 \mathrm{c}$ & $711.80 \pm 136.09 \mathrm{c}$ & & $5,909.32 \pm 1,152.72 \mathrm{c}$ & $1,641.08 \pm 314.45 \mathrm{c}$ \\
\hline
\end{tabular}

Different letters in the same column indicate statistical differences $(p<0.05)$. 
Table 4. Sensory evaluation of fried flakes using palm oil.

\begin{tabular}{clllll}
\hline Parameter & Control & Whey $5 \%$ & Whey $10 \%$ & Fiber $5 \%$ & \multicolumn{1}{c}{ Fiber $10 \%$} \\
\hline Appearance & $3.00 \pm 0.00 \mathrm{AB}$ & $2.79 \pm 0.50 \mathrm{AB}$ & $2.58 \pm 0.67 \mathrm{~A}$ & $3.17 \pm 0.51 \mathrm{BC}$ & $3.61 \pm 0.77 \mathrm{C}$ \\
Aroma & $3.00 \pm 0.00 \mathrm{~A}$ & $3.07 \pm 0.37 \mathrm{~A}$ & $3.17 \pm 0.44 \mathrm{~A}$ & $3.22 \pm 0.48 \mathrm{~A}$ & $3.28 \pm 0.45 \mathrm{~A}$ \\
Crispiness & $3.00 \pm 0.00 \mathrm{~A}$ & $3.28 \pm 0.58 \mathrm{AB}$ & $3.63 \pm 0.79 \mathrm{BC}$ & $3.45 \pm 0.49 \mathrm{ABC}$ & $3.86 \pm 0.59 \mathrm{C}$ \\
Hardness & $3.00 \pm 0.00 \mathrm{~A}$ & $3.40 \pm 0.73 \mathrm{BC}$ & $3.53 \pm 0.32 \mathrm{C}$ & $3.17 \pm 0.36 \mathrm{AB}$ & $3.09 \pm 0.35 \mathrm{AB}$ \\
Taste & $3.00 \pm 0.00 \mathrm{~A}$ & $3.18 \pm 0.33 \mathrm{AB}$ & $2.88 \pm 0.50 \mathrm{~A}$ & $3.58 \pm 0.61 \mathrm{~B}$ & $3.56 \pm 0.71 \mathrm{~B}$ \\
Overall evaluation & $3.00 \pm 0.00 \mathrm{~A}$ & $3.35 \pm 0.59 \mathrm{AB}$ & $3.43 \pm 0.60 \mathrm{AB}$ & $3.88 \pm 0.62 \mathrm{BC}$ & $4.12 \pm 0.62 \mathrm{C}$ \\
\hline
\end{tabular}

Different letters in the same row indicate statistical differences $(p<0.05)$.

\subsection{Sensory evaluation of the fried flakes}

Previous results indicated that palm oil was more suitable for deep frying than coconut oil due to low oil absorption and better availability in the market. A sensory evaluation was conducted to determine the difference among the samples concerning appearance, aroma, crispiness, hardness, taste and overall evaluation. Results showed that the whey and fiber added samples mostly recorded a higher score than the control (Table 4). The sensory scores suggested that the fiber added samples had better appearance, aroma, taste and overall evaluation than whey added samples. The fiber added samples had a softer texture than the whey added samples which contradicted the texture analysis result. The overall evaluation score of the $10 \%$ fiber added samples was the highest, indicating that this formula was the most preferable including the control.

These results can be used by the food industry to formulate a batter that is suitable for consumer demand and to determine the best frying oil for large-scale investment.

\section{Conclusions}

Frying media affects the characteristics of deep-fried products. Coconut oil fried flakes had higher oil uptake, with hardness and stiffness lower than for palm oil. Whey protein and fiber addition did not affect flake density but increased oil absorption. Hardness and stiffness of protein and fiber-added samples were lower than the control and resulted in an improved texture. Whey protein showed higher texture modification than fiber. Oil absorption in fiber-added samples was lower than for whey protein addition. Our results indicated that coconut oil was not a good frying medium in aspects of oil uptake while adding protein or fiber modified the texture of fried batter to levels that were more acceptable than the control.

\section{Acknowledgements}

This project was financially supported by Suwapee Holding Co., Ltd.

\section{References}

Brannan, R. G., Mah, E., Schott, M., Yuan, S., Casher, K. L., Myers, A., \& Herrick, C. (2014). Influence of ingredients that reduce oil absorption during immersion frying of battered and breaded foods. European Journal of Lipid Science and Technology, 116(3), 240-254. http://dx.doi.org/10.1002/ejlt.201200308.
Budžaki, S., \& Šeruga, B. (2005). Determination of convective heat transfer coefficient during frying of potato dough. Journal of Food Engineering, 66(3), 307-314. http://dx.doi.org/10.1016/j. jfoodeng.2004.03.023.

Debnath, S., Bhat, K. K., \& Rastogi, N. K. (2003). Effect of pre drying on kinetics of moisture loss and oil uptake during deep fat frying of chick pea flour-based snack food. Lebensmittel-Wissenschaft + Technologie, 36(1), 91-98. http://dx.doi.org/10.1016/S0023-6438(02)00186-X.

Debnath, S., Rastogi, N. K., Gopala Krishna, A. G., \& Lokesh, B. R. (2012). Effect of frying cycles on physical, chemical and heat transfer quality of rice bran oil during deep-fat frying of poori: An Indian traditional fried food. Food and Bioproducts Processing, 90(2), 249256. http://dx.doi.org/10.1016/j.fbp.2011.05.001.

Dogan, S. F., Sahin, S., \& Sumnu, G. (2005a). Effects of batters containing different protein types on the quality of deep-fat-fried chicken nuggets. European Food Research and Technology, 220(5-6), 502508. http://dx.doi.org/10.1007/s00217-004-1099-7.

Dogan, S. F., Sahin, S., \& Sumnu, G. (2005b). Effects of soy and rice flour addition on batter rheology and quality of deep-fat frying chicken nuggets. Journal of Food Engineering, 71(1), 127-132. http://dx.doi. org/10.1016/j.jfoodeng.2004.10.028.

Dueik, V., Sobukola, O., \& Bouchon, P. (2014). Development of low-fat gluten and starch fried matrices with high fiber content. Lebensmittel-Wissenschaft + Technologie, 59(1), 6-11. http://dx.doi. org/10.1016/j.lwt.2014.04.036.

Gertz, C. (2014). Fundamentals of the frying process. European Journal of Lipid Science and Technology, 116(6), 669-674. http://dx.doi. org/10.1002/ejlt.201400015.

Khan, M. I., Asha, M. R., Bhat, K. K., \& Khatoon, S. (2000). Studies on quality of coconut oil blends after frying potato chips. Journal of the American Oil Chemists' Society, 85(12), 1165-1172. http:// dx.doi.org/10.1007/s11746-008-1299-6.

Kim, J., Kim, D. N., Lee, S. H., Yoo, S. H., \& Lee, S. (2010). Correlation of fatty acid composition of vegetable oils with rheological behavior and oil uptake. Food Chemistry, 118(2), 398-402. http://dx.doi. org/10.1016/j.foodchem.2009.05.011.

Kita, A., \& Lisínska, G. (2005). The influence of oil type and frying temperatures on the texture and oil content of French fries. Journal of the Science of Food and Agriculture, 85(15), 2600-2604. http:// dx.doi.org/10.1002/jsfa.2319.

Kita, A., Lisínska, G., \& Golubowska, G. (2007). The effects of oils and frying temperatures on the texture and fat content of potato crisp. Food Chemistry, 102(1), 1-5. http://dx.doi.org/10.1016/j. foodchem.2005.08.038.

Krokida, M. K., Oreopoulou, V., \& Maroulis, Z. B. (2000). Effect of frying conditions on shrinkage and porosity of fried potatoes. Journal of Food Engineering, 43(3), 147-154. http://dx.doi.org/10.1016/ S0260-8774(99)00143-0. 
Lu, F. S., \& Tan, P. D. (2009). A comparative study of storage stability in virgin coconut oil and extra virgin olive oil upon thermal treatment. International Food Research Journal, 16, 343-354.

Mba, O. I., Dumont, M. J., \& Ngadi, M. (2015). Palm oil: Processing, Characterization and utilization in the food industry-A review. Food Bioscience, 10, 26-41. http://dx.doi.org/10.1016/j.fbio.2015.01.003.

Mellema, M. (2003). Mechanism and reduction of fat uptake in deep-fat fried foods. Trends in Food Science \& Technology, 14(9), 364-373. http://dx.doi.org/10.1016/S0924-2244(03)00050-5.

Mohamed, S., Hamid, N. A., \& Hamid, M. A. (1998). Food components affecting the oil absorption and crispness of fried batter. Journal of the Science of Food and Agriculture, 78(1), 39-45. http://dx.doi.org/10.1002/ (SICI)1097-0010(199809)78:1<39::AID-JSFA82>3.0.CO;2-G.

Moreira, R. G., Sun, X., \& Chen, Y. (1997). Factors affecting oil uptake in tortilla chips in deep-fat frying. Journal of Food Engineering, 31(4), 485-498. http://dx.doi.org/10.1016/S0260-8774(96)00088-X.

Nakamura, S., \& Ohtsubo, K. (2010). Influence of physicochemical properties of rice flour on oil uptake of tempura frying batter. Bioscience, Biotechnology, and Biochemistry, 74(12), 2484-2489. http://dx.doi.org/10.1271/bbb.100584. PMid:21150105.

Nasiri, F. D., Mohebbi, M., Yazdi, F. T., \& Khodaparast, M. H. H. (2012). Effects of soy and corn flour addition on batter rheology and quality of deep-fat fried shrimp nugget. Food and Bioprocess Technology, 5(4), 1238-1245. http://dx.doi.org/10.1007/s11947-010-0423-4.

Olson, S., \& Zoss, R. (1985). US Patent $N^{\circ}$ 4511,583. Minneapolis: General Mills Inc.

Pęksa, A., Miedzianka, J., Kita, A., Czopek, A. T., \& Rytel, E. (2010). The quality of fried snack fortified with fiber and protein supplements. Potravinastro, 4(2), 59-64. http://dx.doi.org/10.5219/54.
Primo-Martín, C., Sanz, T., Steringa, D. W., Salvador, A., Fiszman, S. M., \& van Vliet, T. (2010). Performance of cellulose derivatives in deep-fried battered snacks: Oil barrier and crispy properties. Food Hydrocolloids, 24(8), 702-708. http://dx.doi.org/10.1016/j. foodhyd.2010.04.013.

Shih, F., \& Daigle, K. (1999). Oil uptake properties of fried batter from rice flour. Journal of Agricultural and Food Chemistry, 47(4), 1611-1615. http://dx.doi.org/10.1021/jf980688n. PMid:10564026.

van Koerten, K., Schutyser, M., Somsen, D., \& Boom, R. (2015). Crust morphology and crispness development during deep-fat frying of potato. Food Research International, 78, 336-342. http://dx.doi. org/10.1016/j.foodres.2015.09.022. PMid:28433300.

Varela, P., \& Fiszman, S. M. (2011). Hydrocolloids in fried foods. A review. Food Hydrocolloids, 25(8), 1801-1812. http://dx.doi.org/10.1016/j. foodhyd.2011.01.016.

Voong, K. Y., Norton, A. B., Mills, T. B., \& Norton, I. T. (2018). Characterisation of deep-fried batter and breaded coatings. Food Structure, 16, 43-49. http://dx.doi.org/10.1016/j.foostr.2018.03.002.

Zeng, H., Chen, J., Zhai, J., Wang, H., Xia, W., \& Xiong, Y. L. (2016). Reduction of the fat content of battered and breaded fish balls during deep-fat frying using fermented bamboo shoot dietary fiber. $L W T$, 73, 425-431. http://dx.doi.org/10.1016/j.lwt.2016.06.052.

Zhang, Y., Zhang, T., Fan, D., Li, J., \& Fan, L. (2018). The description of oil absorption behavior of potato chips during the frying. LWT, 96, 199-126. http://dx.doi.org/10.1016/j.lwt.2018.04.094.

Ziaiifar, A. M., Courtois, F., \& Trystram, G. (2010). Porosity development and its effect on oil uptake during frying process. Journal of Food Process Engineering, 33(2), 191-212. http://dx.doi.org/10.1111/j.17454530.2008.00267.x. 